\title{
Non-agglomerated silicon-organic nanoparticles and their nanocomplexes with oligonucleotides: synthesis and properties
}

\author{
Asya S. Levina*1,2, Marina N. Repkova ${ }^{1,2}$, Nadezhda V. Shikina ${ }^{3}$, Zinfer R. Ismagilov ${ }^{3}$, \\ Svetlana A. Yashnik ${ }^{3}$, Dmitrii V. Semenov², Yulia I. Savinovskaya ${ }^{2}$, \\ Natalia A. Mazurkova4 ${ }^{4}$ Inna A. Pyshnaya ${ }^{2}$ and Valentina F. Zarytova*1,2,§
}

\section{Full Research Paper}

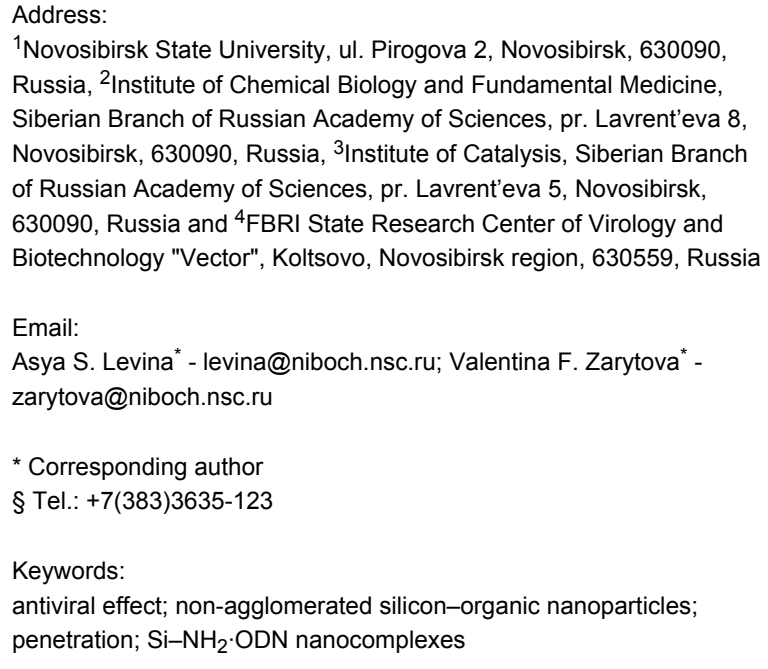

${ }^{1}$ Novosibirsk State University, ul. Pirogova 2, Novosibirsk, 630090, Russia, ${ }^{2}$ Institute of Chemical Biology and Fundamental Medicine, Siberian Branch of Russian Academy of Sciences, pr. Lavrent'eva 8, Novosibirsk, 630090, Russia, ${ }^{3}$ Institute of Catalysis, Siberian Branch of Russian Academy of Sciences, pr. Lavrent'eva 5, Novosibirsk, 630090, Russia and ${ }^{4} \mathrm{FBRI}$ State Research Center of Virology and Biotechnology "Vector", Koltsovo, Novosibirsk region, 630559, Russia

\author{
Beilstein J. Nanotechnol. 2018, 9, 2516-2525. \\ doi:10.3762/bjnano.9.234 \\ Received: 15 March 2018 \\ Accepted: 10 September 2018 \\ Published: 21 September 2018 \\ Associate Editor: J. J. Schneider \\ (C) 2018 Levina et al.; licensee Beilstein-Institut. \\ License and terms: see end of document.
}

\begin{abstract}
The development of efficient and convenient systems for the delivery of nucleic-acid-based drugs into cells is an urgent task. A promising approach is the use of various nanoparticles. Silica nanoparticles can be used as vehicles to deliver nucleic acid fragments into cells. In this work, we developed a method for the synthesis of silicon-organic $\left(\mathrm{Si}-\mathrm{NH}_{2}\right)$ non-agglomerated nanoparticles by the hydrolysis of aminopropyltriethoxysilane (APTES). The resulting product forms a clear solution containing nanoparticles in the form of low molecular weight polymer chains with $\left[-\mathrm{Si}(\mathrm{OH})\left(\mathrm{C}_{3} \mathrm{H}_{6} \mathrm{NH}_{2}\right) \mathrm{O}-\right]$ monomer units. Oligonucleotides (ODN) were conjugated to the prepared $\mathrm{Si}-\mathrm{NH}_{2}$ nanoparticles using the electrostatic interaction between positively charged amino groups of nanoparticles and negatively charged internucleotide phosphate groups in oligonucleotides. $\mathrm{The} \mathrm{Si}-\mathrm{NH}_{2}$ nanoparticles and $\mathrm{Si}-\mathrm{NH}_{2} \cdot \mathrm{ODN}$ nanocomplexes were characterized by transmission electron microscopy, atomic force microscopy and IR and electron spectroscopy. The size and zeta potential values of the prepared nanoparticles and nanocomplexes were evaluated. Oligonucleotides in $\mathrm{Si}-\mathrm{NH}_{2} \cdot \mathrm{ODN}$ complexes retain their ability to form complementary duplexes. The $\mathrm{Si}-\mathrm{NH}_{2}{ }^{\text {Flu }}$ nanoparticles and $\mathrm{Si}-\mathrm{NH}_{2} \cdot \mathrm{ODN}^{\mathrm{Flu}}$ nanocomplexes were shown by fluorescence microscopy to penetrate into human cells. The $\mathrm{Si}_{-} \mathrm{NH}_{2}{ }^{\mathrm{Flu}}$ nanoparticles predominantly accumulated in the cytoplasm whereas $\mathrm{ODN}^{\mathrm{Flu}}$ complexes were predominantly detected in the cellular nuclei.
\end{abstract}


The $\mathrm{Si}-\mathrm{NH}_{2} \cdot \mathrm{ODN}$ nanocomplexes demonstrated a high antisense activity against the influenza A virus in a cell culture at a concentration that was lower than their $50 \%$ toxic concentration by three orders of magnitude.

\section{Introduction}

The development of efficient and convenient systems for the delivery of nucleic-acid-based drugs into cells is an urgent task. The solution to this problem would allow for the use of these drugs in practical medicine. Despite many efforts in this field, this problem cannot be considered as completely solved. A promising approach is the use of various nanoparticles as delivery vehicles. We have previously developed methods for immobilizing DNA fragments onto titanium dioxide nanoparticles with the formation of $\mathrm{TiO}_{2} \cdot \mathrm{PL}-\mathrm{DNA}$ nanocomposites $[1,2]$. Silica nanoparticles can also be used as vehicles to deliver nucleic acid fragments into cells $[3,4]$.

$\mathrm{SiO}_{2}$ nanoparticles bearing amino groups on the surface were shown to bind plasmid DNA, allowing the nanoparticles to penetration into cells, and even nuclei, and to protect DNA against intracellular nucleases $[5,6]$. The prospect of using $\mathrm{SiO}_{2}$ nanoparticles as nonviral nanovectors to deliver plasmid DNA and their lower toxicity compared to the widely used transfection agent lipofectamine was shown in previous work [6]. It was demonstrated that $\mathrm{SiO}_{2}$ nanoparticles with a diameter of 20-77 nm can easily penetrate into cellular cytoplasm and nuclei [7]. Polylysine-modified nanoparticles appeared to be nontoxic upon oral administration in mice, which opens the possibility for their wide application [8]. Under physiological conditions, $\mathrm{SiO}_{2}$ nanoparticles are known to degrade to orthosilicic acid, $\mathrm{Si}(\mathrm{OH})_{4}$, which is found in almost all human tissues and effectively excreted through the urine [9]. Organically modified silica nanoparticles are known for their low toxicity and biocompatibility and can be used for targeted imaging and therapy $[10,11]$.

The synthesis of amino-containing silica nanoparticles has been described in many works [3,6,12-15]. Most often, amino-containing silica nanoparticles are prepared by copolymerization during the hydrolysis of alkyl (or aryl)triethoxy(or methoxy) silanes in the presence of APTES [16,17]. A large series of works describes the synthesis of amino-containing silicon nanoparticles, so-called ORMOSIL, and their use for diagnostics and therapy $[15,18]$. Most often, these methods lead to the formation of nanoparticles with a diameter of $20-100 \mathrm{~nm}$. Silica is particularly attractive as a functional, biocompatible, nontoxic, and inert material, which can be easily synthesized and modified $[16,17]$.

In this work, we describe the synthesis of silicon-based nanoparticles by the hydrolysis of APTES alone, the preparation of oligonucleotide-containing nanocomplexes on their basis, and characterization of both nanoparticles and nanocomplexes. We also demonstrated the biological activity of the latter with an example of inhibition of influenza A virus replication in cell culture.

\section{Results and Discussion}

$\mathrm{Si}-\mathrm{NH}_{2}$ nanoparticles were synthesized by the hydrolysis of aminopropyltriethoxysilane (APTES). The resulting product is a clear aqueous solution containing nanoparticles in the form of low molecular weight polymer chains consisting of the $\left[-\mathrm{Si}(\mathrm{OH})\left(\mathrm{C}_{3} \mathrm{H}_{6} \mathrm{NH}_{2}\right) \mathrm{O}-\right]$ monomer units as shown below.

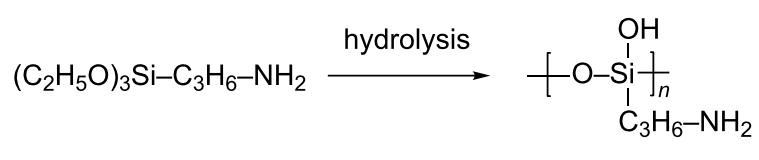

(APTES)

$\left(\mathrm{Si}-\mathrm{NH}_{2}\right)$

Due to the positively charged amino groups in $\mathrm{Si}-\mathrm{NH}_{2}$ at the neutral $\mathrm{pH}$ values, the nanoparticles can be electrostatically conjugated with oligodeoxyribonucleotides (ODN) through the binding to the negatively charged internucleotide phosphate groups to form $\mathrm{Si}-\mathrm{NH}_{2} \cdot \mathrm{ODN}$ complexes. Like $\mathrm{Si}-\mathrm{NH}_{2}$, the $\mathrm{Si}-\mathrm{NH}_{2} \cdot \mathrm{ODN}$ nanocomplexes are dissolved in aqueous solutions. The addition of $\mathrm{NaCl}$ did not lead to precipitation. $\mathrm{Si}-\mathrm{NH}_{2}$ and $\mathrm{Si}-\mathrm{NH}_{2} \cdot \mathrm{ODN}$ can be precipitated by acetone. The unbound oligonucleotide after precipitation of $\mathrm{Si}-\mathrm{NH}_{2} \cdot \mathrm{ODN}$ remains in solution and can be detected spectrophotometrically. This "acetone precipitation" technique allowed us to evaluate the optimal molar ratio of the amino groups in the nanoparticles to the phosphate groups in an oligonucleotide $\left(\mathrm{NH}_{2} / \mathrm{p} \approx 10\right)$ when preparing the $\mathrm{Si}-\mathrm{NH}_{2} \cdot \mathrm{ODN}$ nanocomplexes (Figure 1a).

A similar result was obtained when the mixture of ODN and $\mathrm{Si}-\mathrm{NH}_{2}$ was analyzed by electrophoresis in agarose gel (Figure $1 \mathrm{~b}$ ). The higher the $\mathrm{NH}_{2} / \mathrm{p}$ ratio, the higher complexation occurred; at the ratio of 11 , the band corresponding to the unbound oligonucleotide almost disappeared and the band corresponding to the $\mathrm{Si}-\mathrm{NH}_{2} \cdot \mathrm{ODN}$ complex could be observed at the top of the electrophoregram. The results indicate the binding of several $\mathrm{Si}-\mathrm{NH}_{2}$ nanoparticles to one oligonucleotide molecule.

The binding of the $\mathrm{Si}-\mathrm{NH}_{2}$ molecules to the internucleotide phosphate groups of an oligonucleotide leads to the formation 


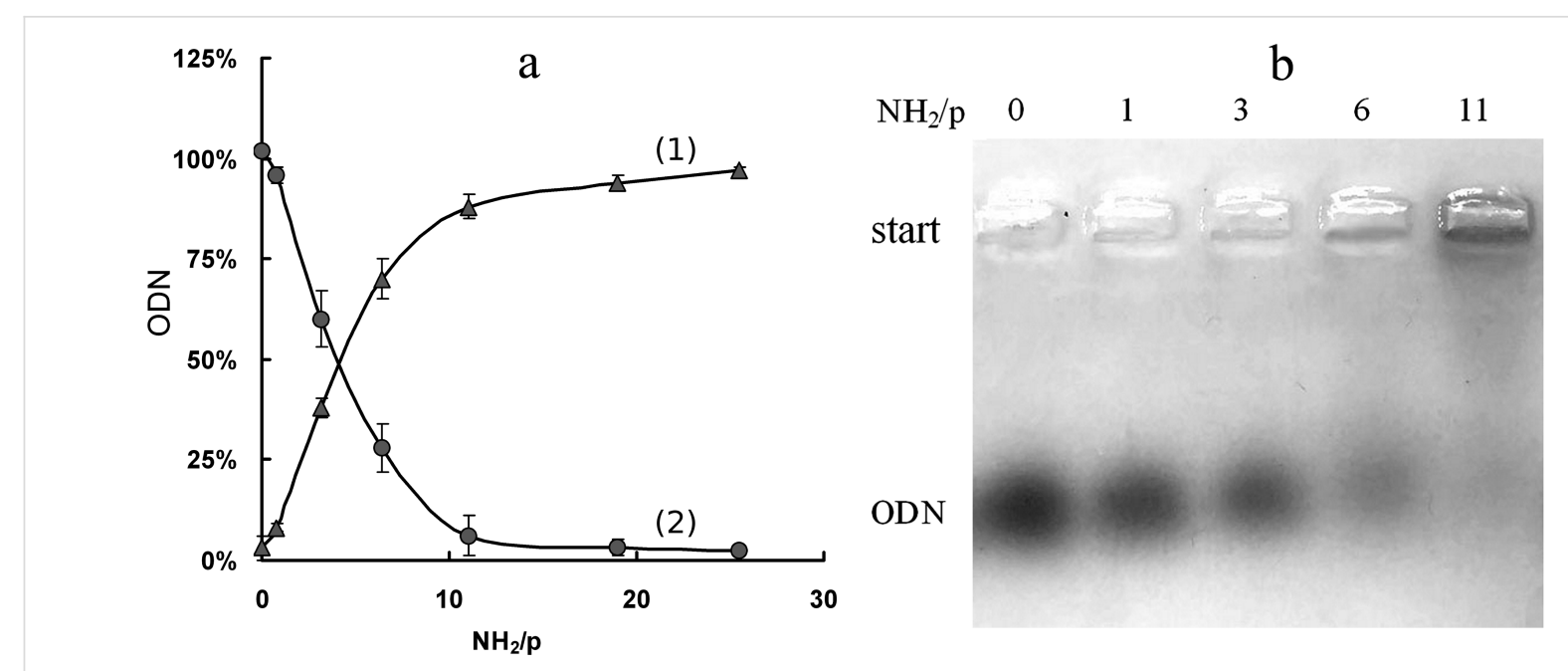

Figure 1: (a) Evaluation of molar ratio of the amino groups in the nanoparticles to the phosphate groups, $\mathrm{NH}_{2} / \mathrm{p}$, for the complete binding of ODN(1) with $\mathrm{Si}-\mathrm{NH}_{2}$ nanoparticles using the "acetone precipitation" technique. The amount of (1) bound and (2) unbound ODN(1) is shown. (b) Electrophoresis in agarose gel.

of an ODN salt. In this work, this salt complex is conventionally named the $\mathrm{Si}-\mathrm{NH}_{2} \cdot \mathrm{ODN}$ nanocomplex.

The $\mathrm{Si}-\mathrm{NH}_{2}$ nanoparticles and $\mathrm{Si}-\mathrm{NH}_{2} \cdot \mathrm{ODN}$ nanocomplexes were characterized by physico-chemical methods.

The IR spectrum of $\mathrm{Si}-\mathrm{NH}_{2}$ shows the local environment of the silicon atom (Figure 2a). The presence of the absorption bands that correspond to valence and deformation vibrations of the $\mathrm{CH}_{2}, \mathrm{NH}_{2}, \mathrm{NH}_{3}{ }^{+}, \mathrm{Si}-\mathrm{CH}_{2}, \mathrm{Si}-\mathrm{OH},(\mathrm{Si}-\mathrm{O})_{n}, \mathrm{C}-\mathrm{N}$ groups [19] confirm the proposed structure of the $\mathrm{Si}-\mathrm{NH}_{2}$ molecule. The splitting of the absorption band at $1085 \mathrm{~cm}^{-1}$, which corre- sponds to asymmetric valence vibrations of the $\mathrm{Si}-\mathrm{O}$ bond, into two bands at $1100 \mathrm{~cm}^{-1}$ and $1000 \mathrm{~cm}^{-1}$ is typical for polymer structures with $\mathrm{Si}-\mathrm{O}-\mathrm{Si}$ fragments and indicates the presence of at least dimers in the $\mathrm{Si}-\mathrm{NH}_{2}$ nanoparticles. The bands at $3058 \mathrm{~cm}^{-1}$ and $1627 \mathrm{~cm}^{-1}$ show the presence of the protonated $\mathrm{NH}_{3}{ }^{+}$groups.

The electron absorption spectrum of the $\mathrm{Si}-\mathrm{NH}_{2}$ solution has two bands at $49000 \mathrm{~cm}^{-1}$ and $36500 \mathrm{~cm}^{-1}(205 \mathrm{~nm}$ and $275 \mathrm{~nm}$, respectively) (Figure 2b), the first of which corresponds to the $\left(\mathrm{n}-\pi^{*}\right)$ transfer and belongs to the $\mathrm{NH}_{2}$ group [19]. The band at $36500 \mathrm{~cm}^{-1}$ can be attributed to the $\mathrm{Si}-\mathrm{O}-\mathrm{Si}$ structures because
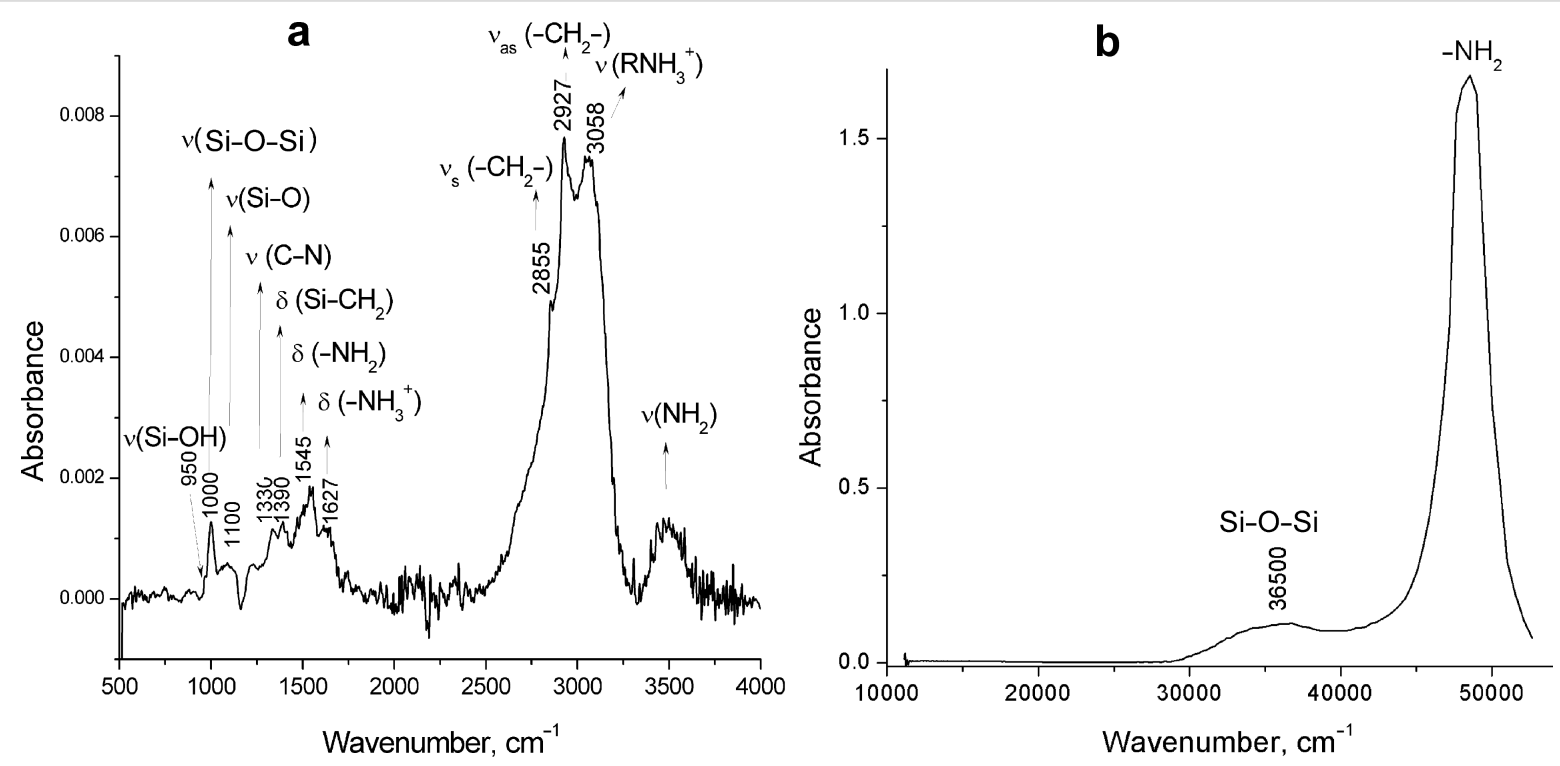

Figure 2: IR (a) and UV (b) spectra of $\mathrm{Si}-\mathrm{NH}_{2}$. 
the absorption in the range of $35000-37000 \mathrm{~cm}^{-1}$ is characteristic for $\mathrm{SiO}_{2}$ nanoparticles and can be caused by electronictype paramagnetic defects or $n-\pi^{*}$ transitions of the adsorbed organic ligand [19].

According to the transmission electron microscopy (TEM) images, there is a difference in morphology between $\mathrm{Si}-\mathrm{NH}_{2}$ nanoparticles and their complexes with ODN. Discrete nanometer-sized nanoparticles $\left(\mathrm{Si}-\mathrm{NH}_{2}\right)$ are quite homogeneous (Figure 3a). $\mathrm{Si}-\mathrm{NH}_{2} \cdot \mathrm{ODN}(1)$ forms chain-like structures (Figure $3 b$ ), which can be explained by the formation of aggregates containing more $\mathrm{Si}-\mathrm{NH}_{2}$ particles. Probably, the $\mathrm{Si}-\mathrm{NH}_{2}$ counter ions in the $\mathrm{Si}-\mathrm{NH}_{2} \cdot \mathrm{ODN}$ complex are polymerized during the sample preparation (drying) due to their close proximity to one other.

The Si/P weight ratio for the analyzed $\mathrm{Si}-\mathrm{NH}_{2} \cdot \mathrm{ODN}(1)$ sample was evaluated by inductively coupled plasma mass spectrome- try (ICP-MS). The experimental Si/P value (10.9) showed a reasonable correlation with the calculated data (10.0).

The atomic force microscopy (AFM) image of the $\mathrm{Si}-\mathrm{NH}_{2}$ nanoparticles was not obtained in a satisfactory quality because of the very small size of the particles. Fortunately, several slightly larger $\mathrm{Si}-\mathrm{NH}_{2} \cdot \mathrm{ODN}(1)$ nanocomplexes could be visualized (Figure 4). According to the AFM data, the size (height) of these nanocomplexes is $1.2-1.5 \mathrm{~nm}$. As in the case of the TEM image (Figure 3b), the particles in the sample can form chainlike structures, which can increase the particle size detected by AFM.

Reasonable results on the diameter of the studied particles were obtained by dynamic light scattering (Table 1 and Table 2), which allows measurement of the particle size in solution (without effects of the drying process, which most likely leads to polymerization and agglomeration of the particles). The zeta
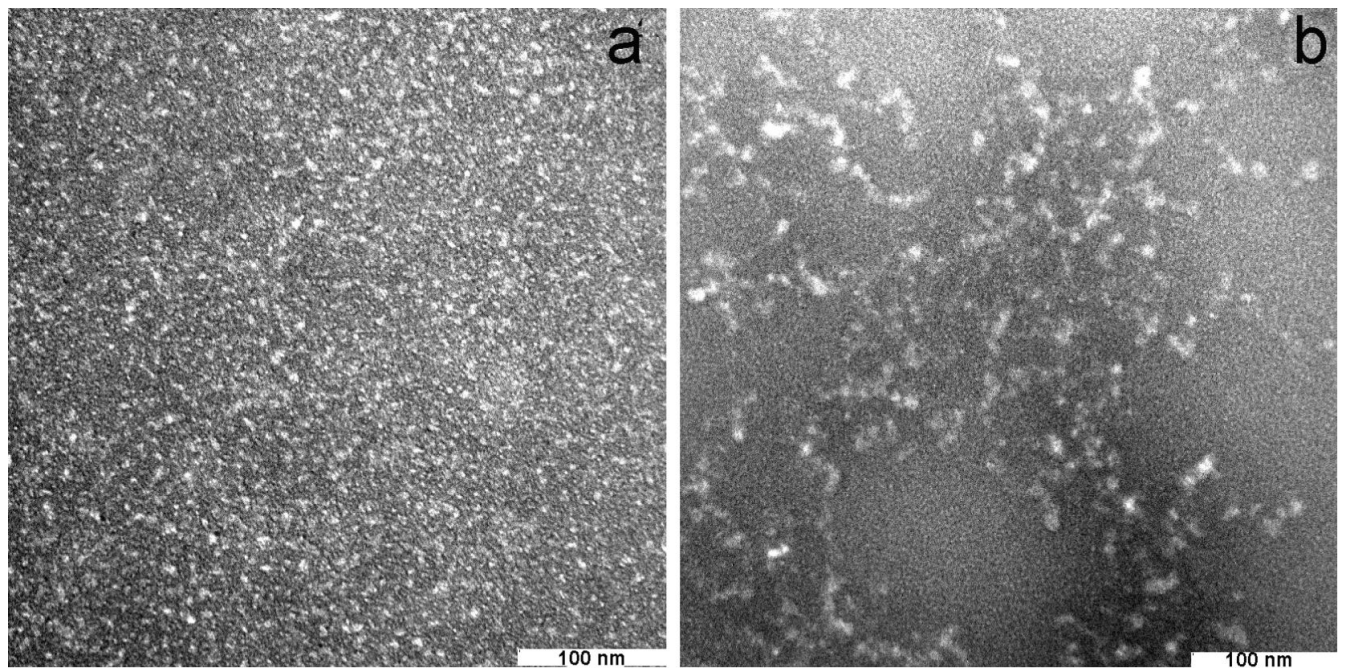

Figure 3: TEM images of $\mathrm{Si}-\mathrm{NH}_{2}$ (a) nanoparticles and $\mathrm{Si}-\mathrm{NH}_{2} \cdot \mathrm{ODN}(1)$ nanocomplexes (b).
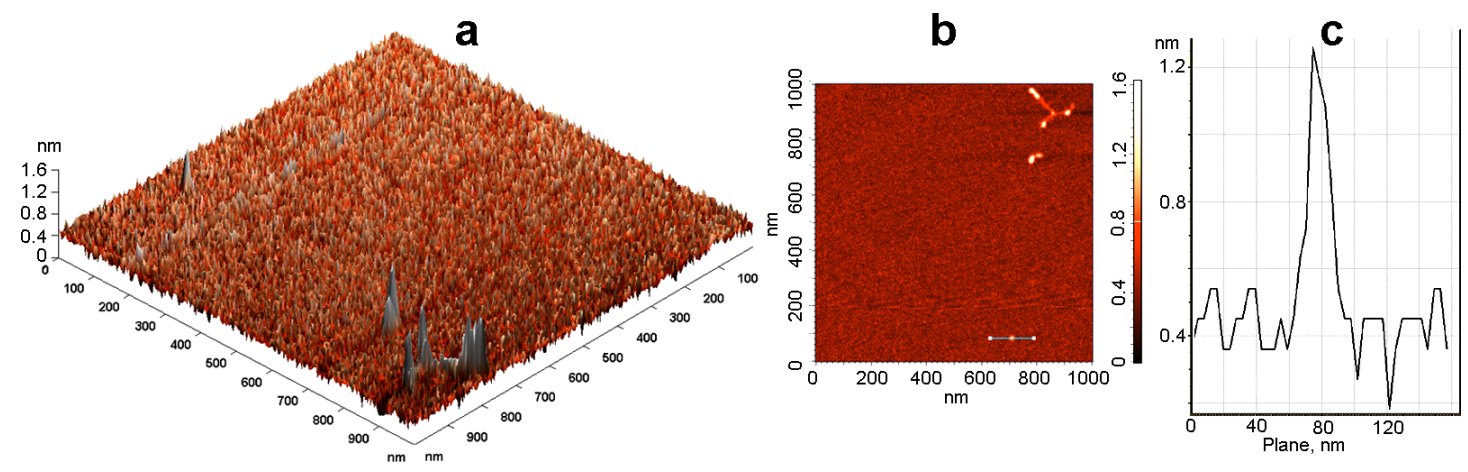

Figure 4: (a) 3D and (b) 2D AFM images of the Si-NH$H_{2} \cdot \mathrm{ODN}(1)$ nanocomplex and (c) a suface profile along the line specified in (b). 
potential of the studied samples was evaluated by phase analysis light scattering. The value of zeta potential of $\mathrm{Si}-\mathrm{NH}_{2}$ is positive due to positively charged amino groups in neutral medium. When the nanoparticles were bound to an oligonucleotide, the zeta potential value, as expected, became negative (Table 1).

$\begin{aligned} & \text { Table 1: Hydrodynamic diameter and zeta potential values of } \mathrm{Si}-\mathrm{NH}_{2} \\
& \text { and } \mathrm{Si}-\mathrm{NH}_{2} \cdot \mathrm{ODN} .\end{aligned}$
\begin{tabular}{lll} 
Sample & $d, \mathrm{~nm}$ & Zeta potential, $\mathrm{mV}$ \\
\hline $\mathrm{Si}-\mathrm{NH}_{2}$ & $1.15 \pm 0.17$ & $+7.9 \pm 0.6$ \\
$\mathrm{Si}-\mathrm{NH}_{2} \cdot \mathrm{ODN}(1)$ & $2.70 \pm 0.23$ & $-14.3 \pm 0.9$ \\
$\mathrm{Si}-\mathrm{NH}_{2} \cdot \mathrm{ODN}(2)$ & $3.56 \pm 0.37$ & \\
$\mathrm{Si}-\mathrm{NH}_{2} \cdot \mathrm{ODN}(3)$ & $3.57 \pm 0.34$ & \\
$\mathrm{Si}-\mathrm{NH}_{2} \cdot \mathrm{ODN}(2) / \mathrm{ODN}(3)$ & $4.82 \pm 0.11$ &
\end{tabular}

A rough estimation of the $\left[-\mathrm{Si}(\mathrm{OH})\left(\mathrm{C}_{3} \mathrm{H}_{6} \mathrm{NH}_{2}\right) \mathrm{O}-\right]$ monomer volume based on the chemical bond lengths $\left(\approx 0.4 \mathrm{~nm}^{3}\right)$ allowed us to assume that the $\mathrm{Si}-\mathrm{NH}_{2}$ nanoparticle $\left(\approx 0.8 \mathrm{~nm}^{3}\right)$ contains about two monomer units, i.e., dimers. The hydrodynamic diameter of the $\mathrm{Si}-\mathrm{NH}_{2} \cdot \mathrm{ODN}$ nanocomplex depends on the length of ODN: compare the sizes of $\mathrm{Si}-\mathrm{NH}_{2} \cdot \mathrm{ODN}(1)$ and $\mathrm{Si}-\mathrm{NH}_{2} \cdot \mathrm{ODN}(2)$ or $\mathrm{Si}-\mathrm{NH}_{2} \cdot \mathrm{ODN}(3)$ containing $15-$ and 19-meric oligonucleotides, respectively (Table 1).

The very small size of the $\mathrm{Si}-\mathrm{NH}_{2}$ particles and $\mathrm{Si}-\mathrm{NH}_{2} \cdot \mathrm{ODN}$ complexes (1-5 nm) allows for the formation of true solutions. The prepared nanoparticles and nanocomplexes, $\mathrm{Si}-\mathrm{NH}_{2}$ and $\mathrm{Si}-\mathrm{NH}_{2} \cdot \mathrm{ODN}$, can be stored for a long time (at least for a month at $25{ }^{\circ} \mathrm{C}$ and three months at $4{ }^{\circ} \mathrm{C}$ ) without changes in size (Table 2), which indicates no aggregation of these preparations occurred in these time frames.

Oligonucleotides in the $\mathrm{Si}-\mathrm{NH}_{2} \cdot \mathrm{ODN}$ nanocomplexes were shown to retain their ability to form complementary duplexes. The $\mathrm{Si}-\mathrm{NH}_{2} \cdot \mathrm{ODN}(2)$ and $\mathrm{Si}-\mathrm{NH}_{2} \cdot \mathrm{ODN}(3)$ nanocomplexes containing the complementary oligonucleotides have the same size $(d \approx 3.6 \mathrm{~nm}$, Table 1); however, we observed an increase in the diameter to $4.8 \mathrm{~nm}$ for the particles in the mixture of these nanocomplexes. This fact indicates the formation of the com- plementary duplex. A similar increase in the size was observed when $\mathrm{ODN}(2)$ was added to the preformed $\mathrm{Si}-\mathrm{NH}_{2} \cdot \mathrm{ODN}(3)$ nanocomplex (Table 1), whereas the additional portion of ODN(3) did not lead to an increase in the size. The melting temperature values for the $\operatorname{ODN}(2) / \mathrm{ODN}(3)$ duplex in the melting buffer (PBS) in the absence and in the presence of $\mathrm{Si}-\mathrm{NH}_{2}$ nanoparticles $\left(T_{\mathrm{m}}=57.5 \pm 0.1{ }^{\circ} \mathrm{C}\right.$ and $57.5 \pm 0.3{ }^{\circ} \mathrm{C}$, respectively) are equal, i.e., the presence of the nanoparticles does not prevent the duplex formation. At the same time, when we studied the duplex formation in the absence of PBS, the duplex was not formed without $\mathrm{Si}-\mathrm{NH}_{2}$ (as expected), whereas the presence of nanoparticles provided the formation of the duplex with the $T_{\mathrm{m}}$ values of $37.6 \pm 0.3{ }^{\circ} \mathrm{C}$ and $52.1 \pm 0.1{ }^{\circ} \mathrm{C}$ at $\approx 1 \mathrm{mM}$ and $10 \mathrm{mM}$ concentration of $\mathrm{Si}-\mathrm{NH}_{2}$, respectively. This experiment additionally confirms the role of $\mathrm{Si}-\mathrm{NH}_{2}$ nanoparticles as counter ions when forming the $\mathrm{Si}-\mathrm{NH}_{2} \cdot \mathrm{ODN}$ complexes.

Fluorescein-labeled nanoparticles $\left(\mathrm{Si}-\mathrm{NH}_{2}{ }^{\mathrm{Flu}}\right)$ are readily detected by fluorescent microscopy in the A549 human epithelial cells after incubation for $8 \mathrm{~h}$ in the culture media (Figure 5, upper panel).

$\mathrm{Si}-\mathrm{NH}_{2}{ }^{\mathrm{Flu}}$ nanoparticles accumulate in microscopic fields related to the cytoplasm. Moreover, one can see that nucleirelated fields are less deeply colored. Under the same conditions, fluorescein-labeled oligonucleotide delivered into cells in the $\mathrm{Si}-\mathrm{NH}_{2} \cdot \mathrm{ODN}(3)^{\mathrm{Flu}}$ nanocomplexes is detected not only in the cytoplasm, but also in nuclei of the human cells (Figure 5, lower panel). Some nuclei are colored more intensely than the cytoplasm in this case.

The biological properties of the proposed $\mathrm{Si}-\mathrm{NH}_{2} \cdot \mathrm{ODN}$ nanocomplexes are demonstrated with an example of the inhibition of the influenza A virus (IAV) replication in the cell culture.

The concentration of $\mathrm{Si}-\mathrm{NH}_{2}$ and $\mathrm{Si}-\mathrm{NH}_{2} \cdot \mathrm{ODN}$ resulting in $50 \%$ MDCK cell death $\left(\mathrm{TC}_{50}\right)$ was found to be $10-20 \mathrm{mM}$ (for $\mathrm{Si})$. The nontoxic concentration of the samples $(0.014 \mathrm{mM}$ for silicon) was used to study their ability to interact with the RNA target in cells with an example using the inhibition of influenza A virus (IAV) reproduction.

\begin{tabular}{|c|c|c|c|c|c|c|c|c|c|c|c|c|}
\hline \multirow{2}{*}{$\begin{array}{l}\text { Sample } \\
T^{\circ} \mathrm{C}\end{array}$} & \multicolumn{6}{|c|}{$\mathrm{Si}-\mathrm{NH}_{2}$} & \multicolumn{6}{|c|}{$\mathrm{Si}-\mathrm{NH}_{2} \cdot \mathrm{ODN}(1)$} \\
\hline & & $4^{\circ} \mathrm{C}$ & & & $25^{\circ} \mathrm{C}$ & & & $4^{\circ} \mathrm{C}$ & & & $25^{\circ} \mathrm{C}$ & \\
\hline Days after preparation & 1 & 30 & 90 & 1 & 30 & 90 & 1 & 30 & 90 & 1 & 30 & 90 \\
\hline$d, \mathrm{~nm}^{\mathrm{a}}$ & 1.05 & 1.21 & 1.10 & 1.16 & 1.23 & - & 2.65 & 2.82 & 2.76 & 2.45 & 2.78 & - \\
\hline
\end{tabular}

astandard deviation for all was between $0.12-0.27$. 


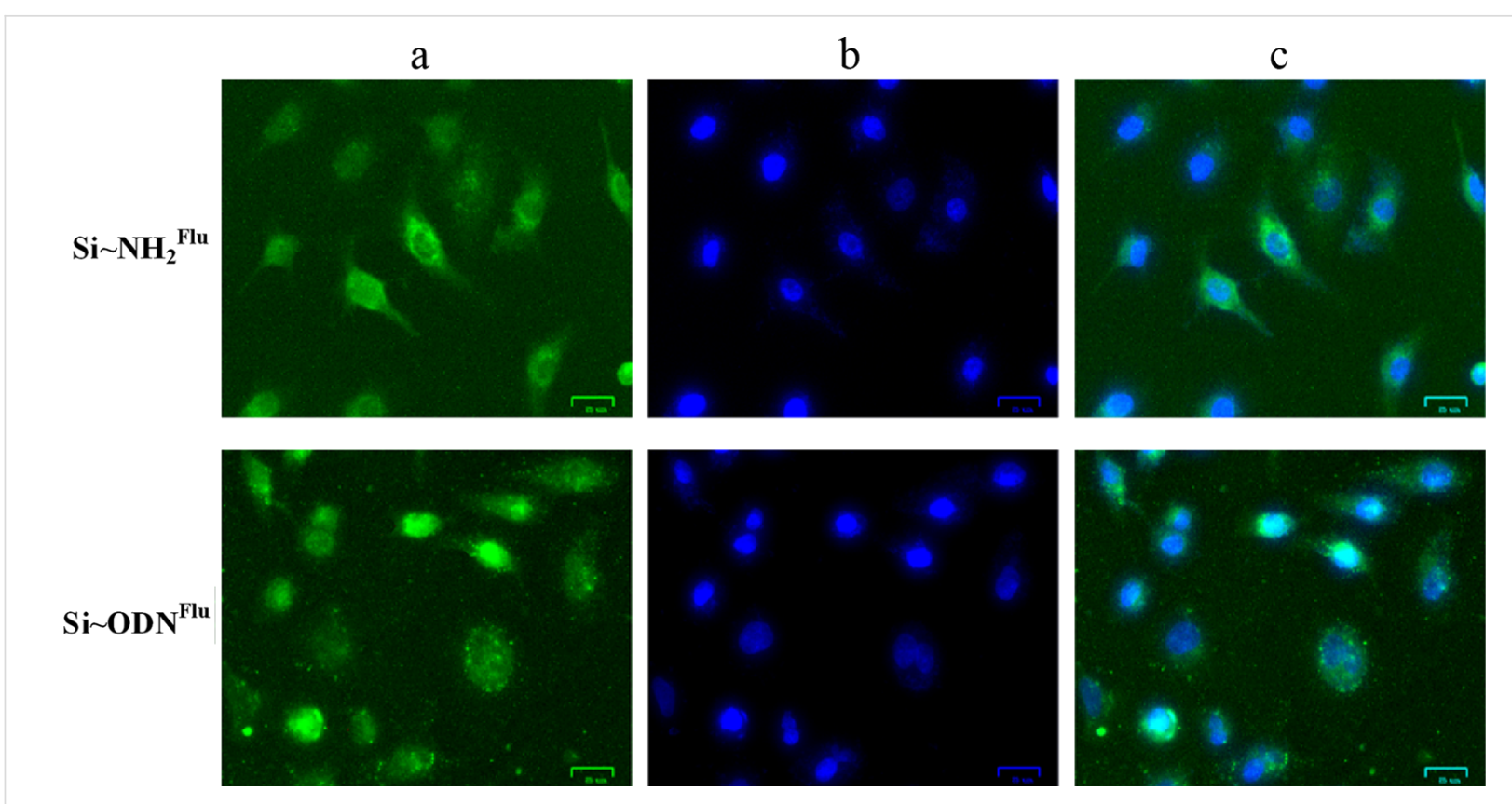

Figure 5: Fluorescence microscopy images of $\mathrm{A} 549$ human lung adenocarcinoma cells after their incubation with $\mathrm{Si}-\mathrm{NH}_{2}$ Flu nanoparticles and $\mathrm{Si}-\mathrm{NH}_{2} \cdot \mathrm{ODN}(3)^{\mathrm{Flu}}$ nanocomplexes. Fluorescein-labeled samples were detected in the green channel $(488 \mathrm{~nm})(\mathrm{a})$; DAPI-stained cell nuclei were detected in the blue channel $(405 \mathrm{~nm})(\mathrm{b})$; the superposition of all channels is shown in (c). The scale bar for all images corresponds to $25 \mu \mathrm{m}$.

The $\mathrm{Si}-\mathrm{NH}_{2} \cdot \mathrm{ODN}$ nanocomplex containing ODN(4) targeted to the 3'-noncoding regions of viral (-)RNA of IAV segment 5 and the control $\mathrm{ODN}(5)$ with a random sequence were assayed for the antiviral activity against avian influenza A virus $\mathrm{H} 5 \mathrm{~N} 1$. MDCK cells were infected at a multicipity of infection (MOI) of $0.1 \mathrm{TCID}_{50} /$ cell. The nanocomplex containing oligonucleotide ODN(4) complementary to viral RNA inhibited the virus reproduction by about three orders of magnitude (Figure 6), whereas $\mathrm{Si}-\mathrm{NH}_{2}$ nanoparticles, unbound $\mathrm{ODN}(4)$, and the nanocomplex containing random $\mathrm{ODN}(5)$ was much less active.

The antiviral activity of the $\mathrm{Si}-\mathrm{NH}_{2} \cdot \mathrm{ODN}(4)$ nanocomplex was not inferior to that of the $\mathrm{TiO}_{2} \cdot \mathrm{PL}-\mathrm{ODN}$ nanocomplexes reported in our previous papers [20-22]. The high inhibition efficiency of the virus reproduction with the use of the $\mathrm{Si}-\mathrm{NH}_{2} \cdot \mathrm{ODN}$ nanocomplex is provided by the fact that the nanocomplex delivers ODN into the cytoplasm of the cell, and ODN can penetrate into the cell nuclei (Figure 5). The delivered ODN can interact with virus RNA via the antisense mechanism.

\section{Conclusion}

We developed a very convenient and simple method for the preparation of non-agglomerated $\mathrm{Si}-\mathrm{NH}_{2}$ nanoparticles and $\mathrm{Si}-\mathrm{NH}_{2} \cdot \mathrm{ODN}$ nanocomplexes. The $\mathrm{Si}-\mathrm{NH}_{2}$ nanoparticles were obtained by a one-step synthesis from APTES, and the resulting product could be used without further purification to form $\mathrm{Si}-\mathrm{NH}_{2} \cdot \mathrm{ODN}$ nanocomplexes. The $\mathrm{Si}-\mathrm{NH}_{2}$ nanoparticles and

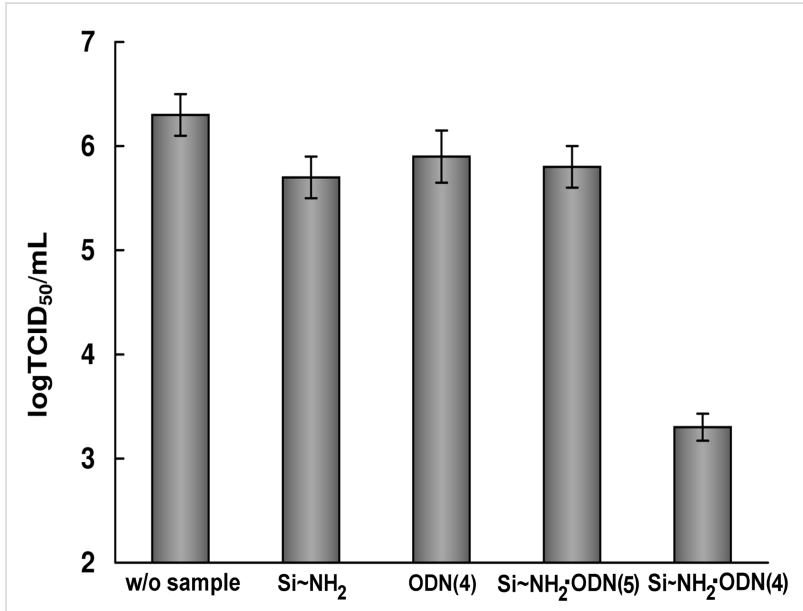

Figure 6: Virus titer $\left(\log \mathrm{TCID}_{50} / \mathrm{mL}\right)$ of $\mathrm{A} /$ chicken/Kurgan/05/2005 virus (H5N1) in the presence of the samples from this study. Experiments were performed in three independent series.

$\mathrm{Si}-\mathrm{NH}_{2} \cdot \mathrm{ODN}$ nanocomplexes were characterized by physicochemical methods. The proposed nanocomplexes appeared to form very small nanoparticles (which are dissolved in aqueous solutions), then penetrate into the cellular cytoplasm to deliver oligonucleotides to the nucleus. The main advantage of the proposed $\mathrm{Si}-\mathrm{NH}_{2}$ nanoparticles and $\mathrm{Si}-\mathrm{NH}_{2} \cdot \mathrm{ODN}$ nanocomplexes is that they are not prone to aggregation and form true aqueous solutions. The $\mathrm{Si}-\mathrm{NH}_{2} \cdot \mathrm{ODN}$ nanocomplexes exhibit biological activity, which has been shown with an example of the inhibition of influenza A virus replication. The proposed nanocom- 
plexes can effectively and selectively interact with RNA targets in the cell culture.

\section{Experimental \\ Materials and methods}

All chemicals were obtained from commercial suppliers as follows: aminiopropyltriethoxysilane (APTES) and fluoresceinisothiocyanate (FITC), trypsin, penicillin-streptomycin, and L-glutamine (Sigma-Aldrich, USA); RPMI-1640 medium; antibiotics (BioloT, Russia); fetal calf serum (Gibco, USA). Chicken erythrocytes, MDCK cells, and influenza A virus strain A/chicken/Kurgan/05/2005 (H5N1) were from FBRI Vector, Russia. Trypsin $(1 \mathrm{mg} / \mathrm{mL})$ and penicillin-streptomycin $(100 \mathrm{U} / \mathrm{mL})$ were stored at $-80{ }^{\circ} \mathrm{C}$. A549 human lung adenocarcinoma cells were from the Russian cell culture collection (Russian Branch of the ETCS, St. Petersburg, Russia). Oligodeoxyribonucleotides (Table 3) were synthesized by the phosphoramidite method on an ASM-800 DNA synthesizer (Biosset, Russia) using phosphoramidite monomers (Glen Research, USA).

Table 3: Oligodeoxyribonucleotides used in the work.

Oligonucleotide $\left(5^{\prime} \rightarrow 3^{\prime}\right)$

\begin{tabular}{ll}
\hline AGCCGTACCCGCGCCp & ODN(1) \\
CTCCGAAGAAATAAGATCCp & ODN(2) \\
GGATCTTATTTCTTCGGAGp & ODN(3) \\
GGATCTTATTTCTTCGGAGp-Flu & ODN(3) Flu \\
GCAAAAGCAGGGTAGATAATCp & ODN(4) \\
GATCAACTCCATATGCCATGTp & ODN(5)
\end{tabular}

The optical absorption of oligonucleotides and their derivatives was measured on a Shimadzu U-1800 spectrophotometer (Shimadzu, Japan).

Inductively coupled plasma mass spectrometry (ICP-MS) was performed using an Agilent 7700 ICP MS (USA) spectrometer.

The IR spectrum of the $\mathrm{Si}-\mathrm{NH}_{2}$ solution was recorded on a Cary 660 FTIR spectrometer (Agilent Technologies, USA) within the range of $4000-500 \mathrm{~cm}^{-1}$ at $4 \mathrm{~cm}^{-1}$ resolution, and 100 scans were accumulated in the attenuated total reflectance (ATR) mode using a GladiATR unit (Pike Technologies). The spectrum of the substance is presented as absorbance after computer processing, in particular, subtraction of the water spectrum (solvent) from the spectrum of the solution was performed (Figure 2a).

The electron spectrum of the $\mathrm{Si}-\mathrm{NH}_{2}$ solution was taken on a Shimadzu UV-2501PC spectrophotometer (Shimadzu,
Japan) in the absorbance mode. The spectrum was recorded with absorption compensation relative to water in the range $11000-54000 \mathrm{~cm}^{-1}$ in a quartz cuvette with an optical path length of $1 \mathrm{~mm}$ (Figure $2 \mathrm{~b}$ ).

The size and zeta potential values of $\mathrm{Si}-\mathrm{NH}_{2}$ and $\mathrm{Si}-\mathrm{NH}_{2} \cdot \mathrm{ODN}$ were measured at 5-50 $\mathrm{mM}$ concentration (for $\mathrm{Si}$ ) in physiological solutions or water on a Zetasizer Nano ZS Plus instrument (Malvern, UK) with the ratio of $\mathrm{NH}_{2} / \mathrm{p}=10$ in the $\mathrm{Si}-\mathrm{NH}_{2} \cdot \mathrm{ODN}$ nanocomplexes. The zeta potential values of the samples were obtained using a DTS1070 cuvette. Each sample was prepared at least in triplicate and measured three times at room temperature. The values of particle size and zeta potential were averaged over those experiments.

Transmission electron microscopy (TEM) images were taken on a JEM 1400 (Jeol, Japan) electron microscope at an accelerating voltage of $80 \mathrm{kV}$.

We analyzed a $35 \mathrm{mM}$ solution of $\mathrm{Si}-\mathrm{NH}_{2}$ nanoparticles and $\mathrm{Si}-\mathrm{NH}_{2} \cdot \mathrm{ODN}$ nanocomplexes with the ratio of $\mathrm{NH}_{2} / \mathrm{p} \approx 10$ in the latter case. The studied sample $(10 \mu \mathrm{L})$ was mixed with a drop of $2 \%$ aqueous uranyl acetate; the mixture was covered with a standard carbon-coated copper mesh and after drying for one minute was fixed in a holder and introduced in the chamber of the electron microscope. The results are presented in Figure 3 .

Atomic force microscopy (AFM) was performed on a Solver P47 Bio atomic force microscope (NT-MDT, Russia) in a tapping mode. The aqueous solution of the $\mathrm{Si}-\mathrm{NH}_{2} \cdot \mathrm{ODN}(1)$ sample $\left(10 \mu \mathrm{L}, 0.16 \mu \mathrm{M}, \mathrm{NH}_{2} / \mathrm{p}=10\right)$ was applied to a freshly cleaved mica area of $25-30 \mathrm{~mm}^{2}$. The adsorption was held for one minute at room temperature; the remaining fluid was blown by air. The results are shown in Figure 4.

\section{Preparation of silicon-organic nanoparticles and $\mathrm{Si}-\mathrm{NH}_{2} \cdot \mathrm{ODN}$ nanocomplexes}

APTES ( $8 \mathrm{~mL}, 34.16 \mathrm{mmol}$ ) was added dropwise to $100 \mathrm{~mL}$ of hot $\left(70^{\circ} \mathrm{C}\right)$ water. The mixture was stirred at this temperature for $15 \mathrm{~h}$ and then cooled to the room temperature. The concentration of the product $(0.46 \mathrm{M})$ was evaluated by inductively coupled plasma mass spectrometry (ICP-MS) on an Agilent 7700 ICP-MS spectrometer or by titration of the amino groups with hydrochloric acid. The yield of the product was 95-97\%.

The resulting $\mathrm{Si}-\mathrm{NH}_{2}$ nanoparticles were attached to oligodeoxyribonucleotides using the electrostatic interaction between the negatively charged internucleotide phosphate groups and positively charged amino groups in $\mathrm{Si}-\mathrm{NH}_{2}$. The amount of 
$\mathrm{Si}-\mathrm{NH}_{2}$ nanoparticles necessary for the complete binding of an oligonucleotide was evaluated in the following experiments. In experiment (a), different amounts of $\mathrm{Si}-\mathrm{NH}_{2}(0,1,3,5,10,16$, and $22 \mu \mathrm{L}$ of $0.046 \mathrm{M}$ solution) were added to $\mathrm{ODN}(1)(2.7 \mu \mathrm{L}$ of $10^{-3} \mathrm{M} ; \approx 40 \mathrm{nmol}$ of phosphate groups) in water in seven vials. The volume of the mixtures was adjusted to $100 \mu \mathrm{L}$ with water in each vial. After vigorous stirring for $1 \mathrm{~min}$, the mixture was left at room temperature for $30 \mathrm{~min}$ to facilitate complexation. The formed $\mathrm{Si}-\mathrm{NH}_{2} \cdot \mathrm{ODN}(1)$ complex was precipitated by acetone (precipitate 1). Supernatants from each vial were separated, and the unbound ODN in these supernatants were precipitated by the addition of $1 \mu \mathrm{L}$ of $3 \mathrm{M} \mathrm{LiClO}_{4}$ (precipitate 2). The precipitates 1 and 2 were dried at $60{ }^{\circ} \mathrm{C}$ to remove the acetone and were dissolved in $1 \mathrm{M} \mathrm{NaCl}$. The amount of the bound (precipitate 1) and unbound (precipitate 2) oligonucleotide was evaluated spectrophotometrically at $260 \mathrm{~nm}$. The results are presented in Figure 1a. In experiment (b), ODN(1) and $\mathrm{Si}-\mathrm{NH}_{2}$ were mixed (as in (a)) and the samples $(1 \mu \mathrm{L})$ were loaded onto $0.7 \%$ agarose gel prepared by heating of agarose in Tris-glycine buffer. Electrophoresis was performed at $5 \mathrm{~V} \cdot \mathrm{cm}^{-1}$ for $30 \mathrm{~min}$. Oligonucleotide spots were visualized by StainsAll (Figure 1b).

In our experiments, the $\mathrm{Si}-\mathrm{NH}_{2} \cdot \mathrm{ODN}$ nanocomplexes were ob-

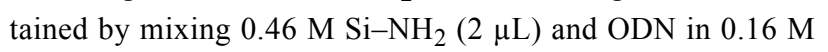
$\mathrm{NaCl}$ or water $(98 \mu \mathrm{L})$ while keeping the ratio between the amino and phosphate groups at $\mathrm{NH}_{2} / \mathrm{p} \geq 10$, unless otherwise specified.

\section{Formation of complementary duplexes}

The $\mathrm{Si}-\mathrm{NH}_{2} \cdot \mathrm{ODN}(2)$ and $\mathrm{Si}-\mathrm{NH}_{2} \cdot \mathrm{ODN}(3)$ nanocomplexes were prepared by mixing $2 \mu \mathrm{L}$ of $46 \mathrm{mM} \mathrm{Si}-\mathrm{NH}_{2}(92 \mathrm{nmol})$ and $2 \mu \mathrm{L}$ of $0.24 \mathrm{mM}$ ODN(2) or ODN(3) $(9.2 \mathrm{nmol}$ of phosphate groups) in physiological solution $(96 \mu \mathrm{L})$. The formed $\mathrm{Si}-\mathrm{NH}_{2} \cdot \mathrm{ODN}(2)$ and $\mathrm{Si}-\mathrm{NH}_{2} \cdot \mathrm{ODN}(3)$ were combined, and their sizes were measured before and after mixing. In another experiment, $\mathrm{ODN}(3)$ or $\mathrm{ODN}(2)(2 \mu \mathrm{L} 0.24 \mathrm{mM})$ was added to the $\mathrm{Si}-\mathrm{NH}_{2} \cdot \mathrm{ODN}(2)$ nanocomplex prepared as above, and the sizes of the particles were measured.

\section{Thermal denaturation of ODN duplexes}

Thermal denaturation of ODN duplexes was studied using a UV-1800 spectrophotometer equipped with a TMSPC-8 instrument (Shimadzu, Japan) for analyzing the melting temperature of the samples. The mixtures of ODN(2) and ODN(3) $(10 \mu \mathrm{L}$, $30 \mu \mathrm{M}$, each) in a PBS buffer $(80 \mu \mathrm{L}), \mathrm{pH} 7.4$, or in water $(80 \mu \mathrm{L})$ was annealed and gradually heated from $5{ }^{\circ} \mathrm{C}$ up to $90{ }^{\circ} \mathrm{C}$ and cooled from $90{ }^{\circ} \mathrm{C}$ to $5^{\circ} \mathrm{C}\left(0.5^{\circ} \mathrm{C} / \mathrm{min}\right)$. The same mixtures in the presence of the $\mathrm{Si}-\mathrm{NH}_{2}$ nanoparticles $(2.6 \mu \mathrm{L}$, $0.042 \mathrm{M}$ or $0.42 \mathrm{M}$, which correspond to a $\mathrm{NH}_{2} / \mathrm{p}$ ratio of 10 or 100 , respectively) were subjected to the same procedure.

\section{Preparation of fluorescently labeled nanoparticles $\left(\mathrm{Si}-\mathrm{NH}_{2} \mathrm{Flu}\right)$ and nanocomplexes $\left(\mathrm{Si}-\mathrm{NH}_{2} \cdot \mathrm{ODN}^{\mathrm{Flu}}\right.$ )}

A mixture of $0.46 \mathrm{M} \mathrm{Si}-\mathrm{NH}_{2}(5 \mu \mathrm{L}, 2.3 \mu \mathrm{mol})$ and $2 \mathrm{mM}$ FITC $(45 \mu \mathrm{L}, 0.09 \mu \mathrm{mol})$ was kept for $1 \mathrm{~h}$ at $60{ }^{\circ} \mathrm{C}$. The reaction mixture was loaded onto a column $(100 \mu \mathrm{L})$ with LichroPrep-C18 pre-equilibrated with $0.05 \mathrm{M} \mathrm{LiClO}_{4}$. Chromatography was carried out in manual mode by stepwise elution using solutions of acetonitrile in water containing $0.05 \mathrm{M} \mathrm{LiClO}_{4}(0,5,10,20$, and $50 \%$ ). Fractions (by $100 \mu \mathrm{L}$ ) were evaporated and analyzed by TLC in an i-propanol- $\mathrm{NH}_{4} \mathrm{OH}$-water mixture $(6: 1: 3)$ on the TLC plates (Merck, Germany). The product containing the fluorescein residue ( $\mathrm{Si}-\mathrm{NH}-\mathrm{Flu}$ ) was revealed mainly in the second fraction $\left(5 \% \mathrm{CH}_{3} \mathrm{CN}\right)$. The mobility of the product in TLC $\left(R_{\mathrm{f}} \approx 0.5\right)$ differed from that of hydrolyzed FITC $\left(R_{\mathrm{f}} \approx 0.65\right)$. The concentration of Si-NH-Flu $(33 \mu \mathrm{M})$ was evaluated spectrophotometrically using the molar absorption coefficient for fluorescein $\left(\varepsilon_{495}=74000 \mathrm{~cm}^{-1} \cdot \mathrm{M}^{-1}\right)$.

For fluorescence microscopy, the $\mathrm{Si}-\mathrm{NH}-\mathrm{Flu}$ product $(3 \mu \mathrm{L}$, $0.1 \mathrm{nmol}$ of the Flu residue) and $46 \mathrm{mM} \mathrm{Si}-\mathrm{NH}_{2}(1 \mu \mathrm{L}$, $46 \mathrm{nmol}$ ) were mixed in $46 \mu \mathrm{L}$ of water, resulting in the solution of $\mathrm{Si}-\mathrm{NH}_{2}{ }^{\text {Flu }}(\approx 1 \mathrm{mM}$ for Si and $2 \mu \mathrm{M}$ for Flu). The labeled $\mathrm{Si}-\mathrm{NH}_{2} \cdot \mathrm{ODN}(3)^{\mathrm{Flu}}$ nanocomplex of the same concentration for $\mathrm{Si}$ and Flu was prepared by mixing $46 \mathrm{mM} \mathrm{Si}-\mathrm{NH}_{2}$ $(1 \mu \mathrm{L}, 46 \mathrm{nmol})$ with $10^{-4} \mathrm{M} \mathrm{ODN}(3)^{\mathrm{Flu}}(1 \mu \mathrm{L}, 0.1 \mathrm{nmol})$ in $48 \mu \mathrm{L}$ of water.

\section{Penetration of nanocomplexes into eukaryotic cells}

A549 human lung adenocarcinoma cells were cultivated in Iscove's modified Dulbecco's media (IMDM; Sigma-Aldrich) with 10\% FBS (Gibco BRL Co., USA), 2 mM L-glutamine (Sigma-Aldrich), and $100 \mathrm{U} / \mathrm{mL}$ penicillin/streptomycin (Gibco BRL Co., USA). The cells were seeded at $2 \times 10^{5}$ cells/chamber in 4-well microscopic chambered cell culture slides (Fisher Scientific, USA) and cultivated for $24 \mathrm{~h}$ in a humidified incubator at $37{ }^{\circ} \mathrm{C}, 5 \% \mathrm{CO}_{2}$. The fluorescein-labeled $\mathrm{Si}-\mathrm{NH}_{2}{ }^{\mathrm{Flu}}$ nanoparticles and $\mathrm{Si}-\mathrm{NH}_{2} \cdot \mathrm{ODN}(3)^{\mathrm{Flu}}$ nanocomplex (final concentration in medium $0.1 \mathrm{mM}$ for $\mathrm{Si}$ and $0.2 \mu \mathrm{M}$ for the Flu residue) were added to the culture media. After incubation for $8 \mathrm{~h}$ at $37{ }^{\circ} \mathrm{C}$, the medium was removed, and the cells were rinsed twice with phosphate buffer saline (PBS), followed by fixation with $4 \%$ formaldehyde $(\mathrm{w} / \mathrm{v})$ in PBS for $20 \mathrm{~min}$ at room temperature. The glass slides were washed twice with PBS and mounted in ProLong antifade mountants (ThermoFisher Scientific, USA). The cells were analyzed with a ZOE Fluorescent Cell Imager (Bio-Rad, USA). Laser lines at $405 \mathrm{~nm}$ (for nuclei, DAPI blue) and $488 \mathrm{~nm}$ (for fluoresceinlabeled samples, green) were used. The results are shown in Figure 5. 


\section{Cell viability assays}

The experiments were carried out similarly as described in [20]. In short: Two days after the formation of a continuous monolayer of MDCK cells at $37{ }^{\circ} \mathrm{C}$ and $5 \% \mathrm{CO}_{2}$, the cells were washed with nutrient medium without serum. The $\mathrm{Si}-\mathrm{NH}_{2}$ or $\mathrm{Si}-\mathrm{NH}_{2} \cdot \mathrm{ODN}$ samples were diluted with RPMI-1640 medium to the needed concentration $(2-35 \mathrm{mM}$ for $\mathrm{Si}$ ) and incubated with MDCK cells at $37{ }^{\circ} \mathrm{C}$ and $5 \% \mathrm{CO}_{2}$ for two days. Destructive changes in the cells were evaluated by an inverted microscope. MDCK cells without studied samples were used as a control and taken for $100 \%$. The cells were stained with trypan blue [23], and the number of viable cells were counted in a Goryaev chamber.

\section{Antiviral activity of nanocomplexes}

The antiviral activity experiments were performed analogously as described in [22]. The influenza A virus (IAV) strains and MDCK cells were prepared as in [22]. The cells at $\approx 80 \%$ confluence were initially infected with A/chicken/ Kurgan/05/2005 virus (H5N1), which was added in each well in RPMI-1640 medium $(100 \mu \mathrm{L})$ containing trypsin $(2 \mu \mathrm{g} / \mathrm{mL})$ at a MOI of 0.1 . The control sample was RPMI-1640 medium $(100 \mu \mathrm{L})$ containing trypsin $(2 \mu \mathrm{g} / \mathrm{mL})$. After $1 \mathrm{~h}$ of virus adsorption at room temperature, the virus-containing medium was removed, and the cells were rinsed with RPMI-1640 medium without trypsin. The $\mathrm{Si}-\mathrm{NH}_{2}, \mathrm{ODN}(4), \mathrm{Si}-\mathrm{NH}_{2} \cdot \mathrm{ODN}(4)$, and $\mathrm{Si}-\mathrm{NH}_{2} \cdot \mathrm{ODN}(5)$ studied samples taken in RPMI-1640 medium without trypsin $(100 \mu \mathrm{L} /$ well $)$ at a concentration of $0.014 \mathrm{mM}$ for $\mathrm{Si}$ and $0.1 \mu \mathrm{M}$ for ODN were applied to the infected MDCK cells, followed by incubation for $4 \mathrm{~h}$ at $37^{\circ} \mathrm{C}$, $5 \% \mathrm{CO}_{2}$, and $100 \%$ humidity. After incubation for $4 \mathrm{~h}$ at room temperature, the medium containing the sample was removed, the cells were rinsed with RPMI-1640 medium without trypsin, and the same medium containing trypsin was added in each well $(100 \mu \mathrm{L})$. After incubation for $48 \mathrm{~h}$, serial ten-fold dilutions (from $10^{-1}$ to $10^{-8}$ ) of the cultural virus-containing liquid from each well were applied to MDCK cells for $48 \mathrm{~h}$ to evaluate the virus titer. The presence of the virus was visually determined under a microscope by the cytopathic action and in the hemagglutination reaction with a $1 \%$ suspension of chicken erythrocytes. The virus titer was expressed in terms of $\log \mathrm{TCID}_{50} / \mathrm{mL}$ (Figure 6). The titer was evaluated by noting the highest dilution of the virus, which caused the hemagglutination reaction.

\section{Acknowledgements}

The authors thank D.V. Korneev for the TEM and AFM studies of the nanoparticles and nanocomplexes. The work was supported by the grant no. 16-15-10073 from the Russian Scientific Foundation. The study of the antiviral activity of the proposed nanocomplexes was supported partially under State funded budget project (VI.62.1.3, 0309-2016-0005) "Therapeutic nucleic acids".

\section{ORCID ${ }^{\circledR}$ iDs}

Asya S. Levina - https://orcid.org/0000-0003-2423-3805 Inna A. Pyshnaya - https://orcid.org/0000-0002-7559-2376

\section{References}

1. Levina, A.; Ismagilov, Z.; Repkova, M.; Shatskaya, N.; Shikina, N.; Tusikov, F.; Zarytova, V. J. Nanosci. Nanotechnol. 2012, 12, 1812-1820. doi:10.1166/jnn.2012.5190

2. Levina, A. S.; Ismagilov, Z. R.; Repkova, M. N.; Shikina, N. V.; Baiborodin, S. I.; Shatskaya, N. V.; Zagrebelnyi, S. N.; Zarytova, V. F. Russ. J. Bioorg. Chem. 2013, 39, 77-86. doi:10.1134/s1068162013010068

3. Liu, Y.; Lou, C.; Yang, H.; Shi, M.; Miyoshi, H. Curr. Cancer Drug Targets 2011, 11, 156-163. doi:10.2174/156800911794328411

4. Roy, I.; Stachowiak, M. K.; Bergey, E. J. Nanomedicine (N. Y., NY, U. S.) 2008, 4, 89-97. doi:10.1016/j.nano.2008.01.002

5. Roy, I.; Ohulchanskyy, T. Y.; Bharali, D. J.; Pudavar, H. E.; Mistretta, R. A.; Kaur, N.; Prasad, P. N. Proc. Natl. Acad. Sci. U. S. A. 2005, 102, 279-284. doi:10.1073/pnas.0408039101

6. Cheang, T. Y.; Tang, B.; Xu, A. W.; Chang, G. Q.; Hu, Z. J.; He, W. L.; Xing, Z. H.; Xu, J. B.; Wang, M.; Wang, S. M. Int. J. Nanomed. 2012, 7, 1061-1067. doi:10.2147/ijn.s28267

7. Neumeyer, A.; Bukowski, M.; Veith, M.; Lehr, C.-M.; Daum, N. Nanomedicine (N. Y., NY, U. S.) 2011, 7, 410-419. doi:10.1016/j.nano.2010.12.007

8. Kneuer, C.; Sameti, M.; Haltner, E. G.; Schiestel, T.; Schirra, H.; Schmidt, H.; Lehr, C.-M. Int. J. Pharm. 2000, 196, 257-261. doi:10.1016/s0378-5173(99)00435-4

9. Park, J.-H.; Gu, L.; von Maltzahn, G.; Ruoslahti, E.; Bhatia, S. N.; Sailor, M. J. Nat. Mater. 2009, 8, 331-336. doi:10.1038/nmat2398

10. Kreuter, J. Adv. Drug Delivery Rev. 2001, 47, 65-81. doi:10.1016/s0169-409x(00)00122-8

11. Mahajan, S. D.; Law, W. C.; Aalinkeel, R.; Reynolds, J. L.; Nair, B. B.; Sykes, D. E.; Yong, K. T.; Roy, I.; Prasad, P. N.; Schwartz, S. A. Int. J. Nanomed. 2012, 7, 5301-5314. doi:10.2147/ijn.s25871

12. Wang, K.; He, X.; Yang, X.; Shi, H. Acc. Chem. Res. 2013, 46, 1367-1376. doi:10.1021/ar3001525

13. Lee, J. E.; Lee, N.; Kim, T.; Kim, J.; Hyeon, T. Acc. Chem. Res. 2011, 44, 893-902. doi:10.1021/ar2000259

14. Tang, F.; Li, L.; Chen, D. Adv. Mater. 2012, 24, 1504-1534. doi:10.1002/adma.201104763

15. Chen, G.; Roy, I.; Yang, C.; Prasad, P. N. Chem. Rev. 2016, 116 , 2826-2885. doi:10.1021/acs.chemrev.5b00148

16. Heidegger, S.; GößI, D.; Schmidt, A.; Niedermayer, S.; Argyo, C.; Endres, S.; Bein, T.; Bourquin, C. Nanoscale 2016, 8, 938-948. doi:10.1039/c5nr06122a

17. Liberman, A.; Mendez, N.; Trogler, W. C.; Kummel, A. C. Surf. Sci. Rep. 2014, 69, 132-158. doi:10.1016/j.surfrep.2014.07.001

18. Kumar, R.; Roy, I.; Ohulchanskyy, T. Y.; Goswami, L. N.; Bonoiu, A. C.; Bergey, E. J.; Tramposch, K. M.; Maitra, A.; Prasad, P. N. ACS Nano 2008, 2, 449-456. doi:10.1021/nn700370b

19. Pan, H.; Li, G.-L.; Liu, R.-Q.; Wang, S.-X.; Wang, X.-D. Appl. Surf. Sci. 2017, 426, 376-385. doi:10.1016/j.apsusc.2017.07.106 
20. Levina, A. S.; Repkova, M. N.; Ismagilov, Z. R.; Shikina, N. V.;

Malygin, E. G.; Mazurkova, N. A.; Zinov'ev, V. V.; Evdokimov, A. A.; Baiborodin, S. I.; Zarytova, V. F. Sci. Rep. 2012, 2, 756.

doi:10.1038/srep00756

21. Levina, A. S.; Repkova, M. N.; Mazurkova, N. A.; Makarevich, E. V.; Ismagilov, Z. R.; Zarytova, V. F. Int. J. Antimicrob. Agents 2015, 46, 125-128. doi:10.1016/j.jjantimicag.2015.03.004

22. Levina, A. S.; Repkova, M. N.; Bessudnova, E. V.; Filippova, E. I.; Mazurkova, N. A.; Zarytova, V. F. Beilstein J. Nanotechnol. 2016, 7, 1166-1173. doi:10.3762/bjnano.7.108

23. Altman, S. A.; Randers, L.; Rao, G. Biotechnol. Prog. 1993, 9 , 671-674. doi:10.1021/bp00024a017

\section{License and Terms}

This is an Open Access article under the terms of the Creative Commons Attribution License

(http://creativecommons.org/licenses/by/4.0). Please note that the reuse, redistribution and reproduction in particular requires that the authors and source are credited.

The license is subject to the Beilstein Journal of Nanotechnology terms and conditions:

(https://www.beilstein-journals.org/bjnano)

The definitive version of this article is the electronic one which can be found at: doi:10.3762/bjnano.9.234 